DIW BERLIN

Discussion

Papers
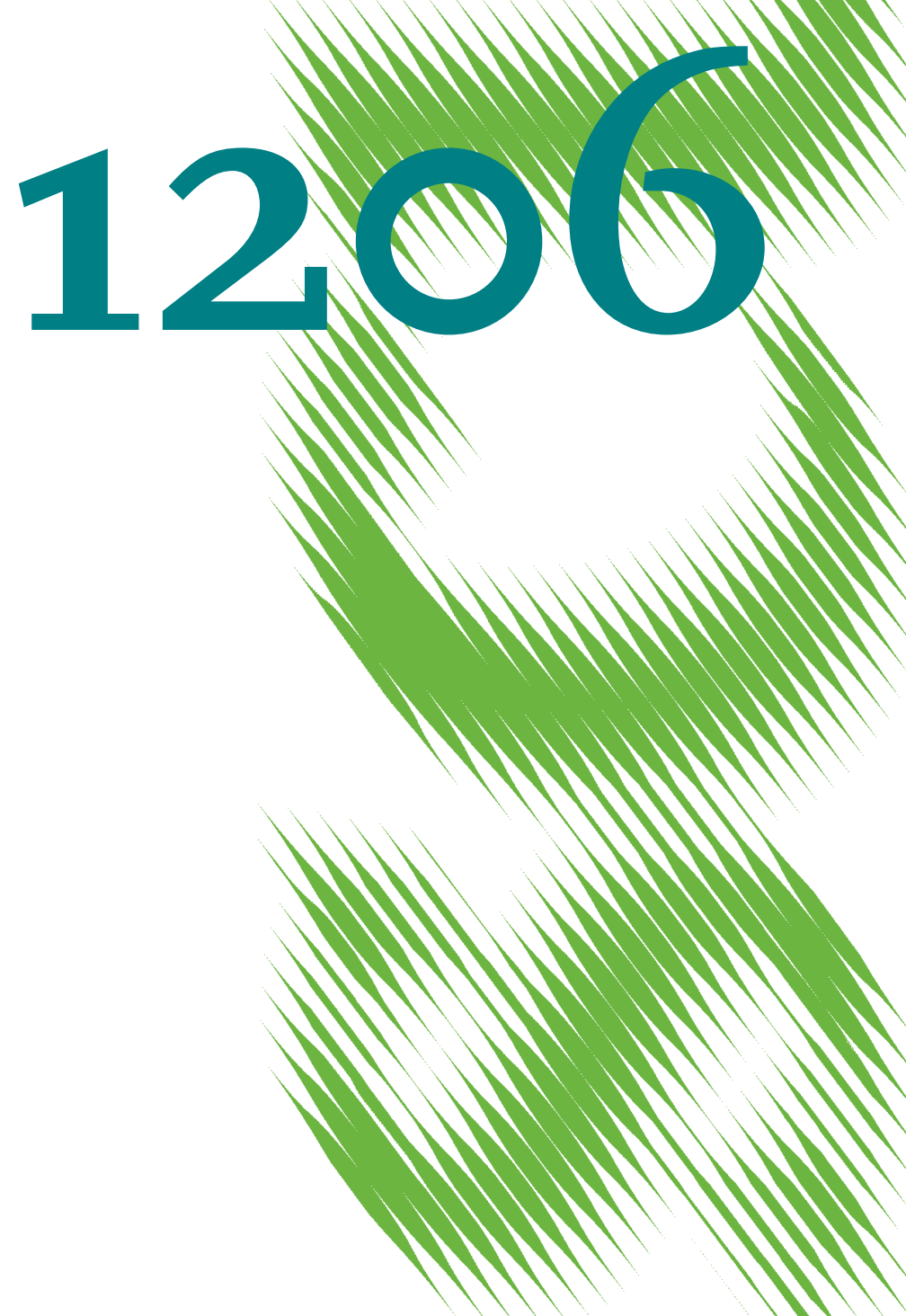

Occupational Sex Segregation and Management-Level Wages in Germany

What Role Does Firm Size Play? 
Opinions expressed in this paper are those of the author(s) and do not necessarily reflect views of the institute.

IMPRESSUM

(C) DIW Berlin, 2012

DIW Berlin

German Institute for Economic Research

Mohrenstr. 58

10117 Berlin

Tel. $+49(30) 89789-0$

Fax +49 (30) $89789-200$

http://www.diw.de

ISSN print edition $1433-0210$

ISSN electronic edition 1619-4535

Papers can be downloaded free of charge from the DIW Berlin website:

http://www.diw.de/discussionpapers

Discussion Papers of DIW Berlin are indexed in RePEc and SSRN:

http://ideas.repec.org/s/diw/diwwpp.html

http://www.ssrn.com/link/DIW-Berlin-German-Inst-Econ-Res.html 


\title{
Occupational Sex Segregation and Management-Level Wages in Germany: What Role Does Firm Size Play?
}

\author{
Anne Busch* and Elke Holst**
}

\begin{abstract}
The paper analyzes the gender pay gap in private-sector management positions based on German panel data and using fixed-effects models. It deals with the effect of occupational sex segregation on wages, and the extent to which wage penalties for managers in predominantly female occupations are moderated by firm size. Drawing on economic and organizational approaches and the devaluation of women's work, we find wage penalties for female occupations in management only in large firms. This indicates a pronounced devaluation of female occupations, which might be due to the longer existence, stronger formalization, or more established "old-boy networks" of large firms.
\end{abstract}

JEL Classification: B54, J16, J24, J31, J71, L2, M51

Keywords: Gender pay gap, managerial positions, occupational sex segregation, gendered organization, firm size

Contact: anne.busch@sowi.hu-berlin.de, eholst@diw.de

* University of Bielefeld, Humboldt University Berlin, DIW Berlin/SOEP

** DIW Berlin/SOEP, Flensburg University 


\section{Introduction}

Many national and international studies on the gender pay gap show a wage disadvantage for women (Blau, Ferber, \& Winkler, 2006; Blau \& Kahn, 2000, 2003; European Commission, 2006; European Foundation for the Improvement of Living and Working Conditions, 2007; Marini, 1989). Germany’s (raw) gender wage gap in 2008 was 23.2 percent, one of the highest in the European Union (European Commission, 2010). However, few articles to date have examined the gender pay gap in management positions in Germany (Busch \& Holst, 2010, 2011; see for other countries Bertrand \& Hallock, 2001; Cohen, Huffman, \& Knauer, 2009; Kirchmeyer, 2002; Lausten, 2001; see for academic professions in Germany: Leuze \& Strauß, 2009). The present study seeks to fill this lacuna: Using advanced panel methods, it analyzes the gender pay gap in private-sector management positions in Germany based on data from the German Socio-Economic Panel Study (SOEP). The specific objective is to find out to what extent occupational sex segregation - the unequal distribution of women and men across occupations-affects earnings and gender wage differentials in management positions. Firm size is taking into account as an important moderator of the effect between occupational sex segregation and wages.

In Germany, as in other countries, segregation has remained very stable over time (European Commission, 2010): Most women still work in predominantly female occupations (so-called “women's occupations”) and most men in predominantly male occupations (“men’s occupations”). Compared to other European member states, Germany lies somewhere in the middle with regard to gender segregation (Smyth \& Steinmetz, 2008). The segregated structure of the German labor market is a broader societal problem because it reproduces inequality between women and men: Predominantly female occupations are generally characterized by worse employment conditions on average-for instance, lower wages (European Commission's Expert Group on Gender and Employment (EGGE), 2009). The 
question that has not been fully answered to date is to what extent this wage penalty to women's occupations also exists in management positions (but see Cohen et al., 2009) and whether this effect is moderated by other variables.

Turning to the theoretical explanations for wage penalties in women's occupations, we hypothesize in this paper that such wage penalties are less prevalent among managers as they are "the best of the best." However, it must be taken into consideration that processes of gender-specific occupational channeling and discrimination in working life are not constant throughout the entire labor market but vary depending on context: Wage penalties to managers in women's occupations may become observable when considering the size of the firm as moderator, an aspect that has not been analyzed in previous studies. Although large firms have many advantages over small firms (e.g., higher wages), we argue here that for managers, processes of devaluation taking place in women's occupations are more prevalent in large firms than in small firms. Therefore, taking the occupational gender composition as a single indicator explaining wages without taking the firm size into account may underestimate wage penalties in women’s occupations in managerial positions.

The study is structured as follows. In Section 2, we introduce the key theories explaining the dependency between occupational sex segregation and wages, discuss the current state of research, and formulate our working hypotheses with regard to management positions. In section 3, we present the multivariate method for quantitative analysis of wages in management positions. In Section 4, we present our database and variables, and in Section 5 we discuss the empirical findings. Finally, in Section 6, we summarize the results and draw conclusions. 


\section{Theoretical background}

\section{Human capital and devaluation}

From an economic point of view, gender-specific wage inequalities in general and wage penalties to women's occupations (compared to men's occupations) in particular can be explained by gender-specific investments in human capital (Becker, 1975). The central assumption underlying this view is that women have stronger family-related preferences than men and that this affects their choices of occupations and career paths. Investments in education and work experience would appear less profitable to women who plan to take breaks from their careers due to family responsibilities, given that accumulated knowledge becomes obsolete during breaks in employment (Blau et al., 2006; Mincer, 1962). As a result, women invest less in human capital.

Building on these assumptions, one can explain the different proportions of women and men in certain occupations and thus the emergence of occupational sex-segregation as well as wage penalties to women's occupations using the concept of self-selection (Polachek, 1981): Women rationally choose particular jobs that have lower opportunity costs, meaning jobs in which the need for human capital accumulation and the deprivation of accumulated human capital during employment breaks is relatively low. Correspondingly, women choose occupations that require lower qualification levels. Wages in such jobs are low c.p. because they do not have to compensate the high costs of human capital accumulation. The theory assumes that starting wages are relatively high in women's occupations compared to men's occupations, but that the wage increase over time is lower. To sum up, women and men "sort" themselves into different occupations with different qualification requirements fitting their different levels of human capital accumulation and preferences. Therefore, a negative effect of occupational sex composition on wages can be explained by the different qualification levels required. 
However, studies using human capital theory to explain the negative effect of occupational sex composition on wages have produced mixed results. In the early 1980s, it was shown that women who planned to interrupt their careers did not, contrary to the hypothesis of selfselection, choose "female" jobs at a higher rate than other women (England, 1982; Okamoto \& England, 1999). Further, research shows that women's occupations do not have higher starting wages than men's occupations (England, Farkas, Kilbourne, \& Dou, 1988). This stands contrary to the assumption that women choose women's occupations to minimize opportunity costs.

On the other hand, in line with human capital theory, research by Tam explained lower wages in women's occupations with lower requirements for specific human capital (Tam, 1997, 2000). Following his arguments, human capital accumulation not only has a general component (schooling and vocational education) but also a specific component, meaning further specialized training in the job. Investments in specific human capital require even higher costs than investments in general human capital, because the employed person is confronted with additional opportunity costs: accumulated specialized knowledge is less transferrable to other jobs than general knowledge. But these investments also offer higher benefits in form of higher future wage increases. Therefore, they also require greater continuity in working life to fully gain these benefits. ${ }^{1}$ For women, the opportunity costs are again higher here, because the theory assumes that women plan for low continuity in working life due to their family preferences. Therefore they invest to a lower extent in specific human capital. With this, according to Tam, women's occupations offer lower wages not only because they require lower qualification levels (general human capital), but also because they require lower specialized knowledge and investments in on-the-job training (specific human capital). Men's occupations, on the other hand, are often highly specialized occupations with much on-the-job training, resulting in higher wages (for a critique of these arguments, see England, Hermsen, \& Cotter, 2000). 
The question is if these theoretical arguments are applicable to management positions: First of all, it can be assumed that female and male managers rarely differ in their human capital accumulation, because only individuals with a high human capital accumulation reach these high positions. Studies show that women and men in managerial positions in Germany are relatively similar in their human capital endowments (Holst \& Busch, 2010). Therefore male and female leaders should not sort to a large extent into different occupations with different human capital requirements. Secondly, segregation also includes a vertical dimension: Women's occupations are often located at lower hierarchical levels (Maume, 1999; Wirth, 2001). Therefore, focusing on management positions already excludes many predominantly female jobs. For Germany it has been shown that segregation also exists in managerial positions, but at a lower level than for non-managers (Holst \& Busch, 2010). Therefore the variance to be explained is smaller for managers, which also reduces the effects of segregation on wages, and the remaining women's jobs may be more similar to men's jobs in human capital requirements.

Beyond the studies mentioned above that contradict assumptions from economic theory, the implicitly "given” gender-specific preferences in the human capital approach were criticized early on in the research (e.g. England, 1989; Ferber, 1987). In the disciplines of sociology and social psychology, other approaches have been formulated to explain the wage penalty to women's occupations. It has been assumed that the historically dominant “male breadwinner" model, in which women are responsible for the unpaid housework and men for the paid work outside the home, leads to corresponding gender-specific values and norms internalized by individuals through their socialization—and thus to gender-specific orientations and needs (“preferences”) for special jobs (Marini \& Brinton, 1984), as well as to discriminatory practices on the labor market (Reskin, McBrier, \& Kmec, 1999).

The internalization of gender roles in values and norms is (re)produced by "doing gender” in everyday interaction processes (West \& Zimmerman, 1987): In order to reduce the amount 
and complexity of information in daily face-to-face interactions, people make gender-specific assumptions about the person with whom they are interacting (Blumer, 1969). This process forms the basis for gender stereotypes that are shaped by cultural perceptions about what constitutes "male" and "female"-and these categorizations are not neutral but implicitly posit a status hierarchy (Keller, 1985; Nelson, 1996; Ridgeway, 1997): men and women are expected to differ in their abilities to fulfill the demands of a certain situation and are therefore assigned different status levels (see for status characteristic theory and expectation states theory: Berger, Fisek, Norman, \& Zelditch, 1977; Ridgeway, 2001).

On the labor market, women are often seen as less efficient and competent to fulfill the demands of work, and are therefore assigned a lower status (Correll \& Ridgeway, 2006). The background of this valuation is that individual characteristics such as being "rational" or "analytical” are seen as important requirements for efficient work on the labor market. These characteristics are highly valued and, at the same time, seen as typically masculine. Being "emotional," on the other hand, is attributed as a typically feminine trait that evolved through care responsibilities within the home, and this trait is valued lower ("emotional work don't 'count'", England, 1989: 24). Accordingly, expectations about potential performance differ by gender-and this may result in wage penalties for women.

All this has consequences on wages, especially for women's occupations: the devaluation hypothesis postulates that predominantly female occupations are valued less (England, 1992; Steinberg, 1990). This devaluation has a quantitative and a qualitative aspect: first, devaluation occurs because women, the lower-status group on the labor market, form the majority within particular occupations (quantitative aspect). Second, devaluation occurs because the content of women's occupations is often related to "feminine" attributes-which are valued lower on the labor market, leading to further devaluation of women's occupations (qualitative aspect). 
Research has found that after taking relevant individual and occupational human capital characteristics into account in the model, there is still a remaining significant wage penalty to predominantly female occupations compared to male occupations. This may be interpreted as an effect of devaluation (England et al., 1988), although such a "residual” interpretation should be taken with caution. Further, for the US, it has been shown that occupations with typically "feminine” tasks such as caring and nurturing show wage penalties (Kilbourne, England, Farkas, Beron, \& Weir, 1994). A similar wage penalty has been found in a German study for jobs involving deskwork and cleaning (Liebeskind, 2004). There, the inclusion of "feminine” tasks in the models decreased the significant negative wage effect of working in a women's occupation. This indicates that the wage penalty in women's occupations can be explained at least partly by the female work tasks involved in these occupations (ibid.).

Again, one can ask whether processes of devaluation are applicable to management positions to the same degree as to other positions on the labor market: As stated before, high-status positions are very uncommon in women's occupations, in which devaluation is particularly high. Furthermore, typically "feminine” tasks, which could lead to further devaluation, are less often typical of the content of managerial positions. Therefore, both quantitative and qualitative conditions of devaluation are not given there.

Based on these assumptions, we can formulate the following hypothesis on the dependency between segregation and wages in managerial positions:

H1: In management positions, there is no significant wage penalty to women's occupations observable-even when taking other characteristics of general and specific human capital into account. This differs from non-management positions, in which we observe a significant wage penalty in women's occupations. 
The effect of segregation on wages—moderator firm size

The question, however, is whether characteristics of the firm, and in particular firm size, moderate this effect of wage penalties to predominantly female occupations due to devaluation in management positions. The devaluation of women's occupations and the higher valuation of men's occupations might appear more pronounced for managers after differentiating between large firms and medium/small firms. All of the approaches described so far fail to take into consideration that processes of gender-specific occupational channeling and discrimination in working life might vary in different labor market contexts. We turn now to organization theory which states that organizations are the central "control points" determining how women and men are integrated into the labor market, and they play an important role in the production and reproduction of social inequality (Achatz, Fuchs, von Stebut, \& Wimbauer, 2002). This idea rests on the assumption that organizations on the labor market create the context for the emergence and legitimization of gender inequalities, but that they are also capable of rendering these difference irrelevant (Achatz, 2008: 121-122). The concept of "gendered organizations" assumes that the differentiation between women and men is a basic element of organizations, and that it is embedded in every organizational structure and process (Acker, 1990). With this, the construction of gender-specific divisions is institutionalized at the organizational level. Organizations establish gender-specific norms that are based on the life realities of men, ignoring the double burdens of family and career (Achatz, 2008).

The assumption that organizations moderate the degree of gender inequality on the labor market is the focus of several articles and studies carried out in Germany (Achatz, 2008; Achatz et al., 2002; Allmendinger \& Podsiadlowski, 2001). Also gender-specific segregation and its consequences (primarily related to wages) has been analyzed in both job-specific and firm-specific settings (Achatz, Beblo, \& Wolf, 2010; Achatz, Gartner, \& Glück, 2005; 
Allmendinger \& Hinz, 2007; Beblo, Heinze, \& Wolf, 2008; Heinze \& Wolf, 2010; Hinz \& Gartner, 2005; Hultin \& Szulkin, 2003).

One important characteristic of the organization where employees work in is the firm size: Studies show that large firms provide many advantages to workers compared to small firms. This becomes apparent in higher wages, better promotion opportunities, and lower segregation in large firms than in small ones (Bielby \& Baron, 1983; Evans \& Leighton, 1988; Hinz \& Schübel, 2001; Lester, 1967). Although it still unclear how these dependencies emerge, one explanation for the observed promotion advantages in large firms is the existence of internal labor markets (Doeringer \& Piore, 1971). The term “internal labor market” describes firm-specific promotion structures. These are assumed to exist especially in firms with a high number of employees. People are hired at a certain level in the firm hierarchy and climb the career ladder within the firm. As part of this process, they acquire firm-specific qualifications (specific human capital, see above). In higher positions, therefore, the probability of recruiting personnel from outside the firm decreases, while that of promoting internal personnel increases. The rules of the internal labor market are different from those of the general labor market; the main mechanism of the labor market - the supply-demand relation—does not hold for internal labor markets.

However, taking "gendered organizations" in mind, the advantages of large firms concerning promotion opportunities are gender-biased: Empirical studies show that small firms have a higher percentage of women in high hierarchical positions (Hoppenstedt, 2010). In Germany, the executive boards of the 200 largest companies are still almost all male (Holst \& Schimeta, 2011). This appears to reinforce the argument that men benefit more from the advantages large firms offer, whereas women hit a "glass ceiling” (Wirth, 2001) or have to find their way through a "labyrinth" (Eagly \& Carli, 2007) Especially navigating a career path through the complex organizational context of large firms is difficult-particularly for women. Gender- 
specific ascriptions play a strong role in internal labor markets since the recruitment of personnel is affected by male networks and informal information flows within the firm.

Another aspect suggesting that the advantages large firms offer may be gender-biased is the observation that large firms are often older than small firms (Brüderl \& Schüssler, 1990). Traditional gender roles that were predominant when an older firm was established may still be embedded in the organizational structure. Thus, the degree of "genderedness"- that is, how entrenched discriminatory practices are within an organizational structure-may be higher in large firms, where processes may tend to devalue women's occupations and attribute higher values to men's occupations. It can therefore be assumed that although segregation itself may be less prevalent and wages in general higher in large firms, processes of devaluation of women's occupations may be more prevalent in large firms. In other words: there are wage advantages of large firms_-but much more for those working in men's occupations, not or much less for employees in women's occupations. This may be especially pronounced among managers: Here, the variance in wages between men's and women's occupations is particularly high in large firms, since most of the highly paid top management positions are in typically men's occupations. Therefore, management jobs in men's occupations are particularly high paid in large firms, whereas the few management jobs in women’s occupations may not differ so strongly in wages between large and small firms.

Small firms, in contrast, are often younger; they have more flexible structures and are therefore able to react more quickly and flexibly to social developments and to integrate women to a larger extent. ${ }^{2}$ Here, both women and men have to climb fewer steps to enter managerial positions, and the "labyrinth" women are faced with is smaller and less complex. Further, if women direct the firms — which again is more prevalent in small firms — they have the power to overcome devaluation processes and pay higher wages to persons working in women's occupations, diminishing the negative effect of the gender composition on wages. Research shows that the gender wage gap is smaller where there are more women in high- 
status managerial positions (Cohen \& Huffman, 2007). Therefore, especially for managerial positions, we can expect to see a smaller devaluation effect in small firms, and a larger effect in large firms.

Therefore, we hypothesize:

H2: Wage penalties to managers in women's occupations are more prevalent in large firms than in small firms. When controlling for human capital, this indicates devaluation.

\section{Models and Estimation Methods}

We first estimate a wage equation according to Mincer (Mincer, 1974) with additional independent variables presented in the next section. The models are estimated separately for women and men. Our analytical strategy is multiple linear panel regression with fixed effects (Allison, 2009). Such models use only within-person changes over time, and the main advantage is that they control for time-constant unobserved heterogeneity. One consequence is that variables that vary between but not within persons (such as gender and personality traits) are excluded from the model.

The fixed effects model can be performed in two ways: First, the "dummy variable strategy" that includes one dummy variable for each individual i in the data set can be used to control for person-specific characteristics that do not vary over time t. The other strategy that produces the same result is to compute the person-specific means over time for each person and each time-varying variable (for both the independent variables $\mathrm{X}_{\mathrm{t}}$ as well as the dependent variable $Y_{t}$ ). After that, for each variable, the difference from its person-specific mean is calculated across years. 


$$
\begin{aligned}
& \text { (1) } Y_{i t}^{*}=Y_{i t}-\bar{Y}_{i} \\
& \text { (2) } X_{i t}^{*}=X_{i t}-\bar{X}_{i}
\end{aligned}
$$

Then a regression of $\mathrm{Y}^{*}$ on $\mathrm{X}^{*}$ can be computed, which shows the effects of individual changes in the independent variables on changes in the dependent variable (here: wages).

$$
Y_{i t}^{*}=\beta_{0}+\beta_{1} X_{i t}^{*}+e_{i t}
$$

However, there might also be another kind of selection bias that is not controlled for in the fixed effects model per se: the selection into managerial positions. Women who are in a management position might be highly selected, which may result in an overestimation of their wages and in biased coefficients. To correct for such a selection bias, we use a special version of Heckman's correction (Heckman, 1979) that is applicable for fixed effects regression (Berk, 1983; England et al., 1988). Here, for each year of the time period in our panel, we perform a cross-sectional logit regression model that predicts working in a management position for women and men. From these equations, we compute an instrumental variable that is the predicted probability of holding a managerial position (versus not holding a managerial position) for women and men in each year. This instrumental variable is added to the wage equations to control for sample selectivity bias. A common method is to estimate a probit model and use the inverse Mills ratio as an instrumental variable (Greene, 2003). In this paper, we used the predicted probabilities based on logit models as described above because the results of the variable can be interpreted in a more straightforward manner. However, we also estimated a probit model and calculated the inverse Mills ratio, and the coefficients did not differ between the two strategies. 


\section{Data and Determinants of Wages}

The wage estimations are based on data from the German Socio-Economic Panel Study (SOEP) for the years 2000-2009 (Wagner et al. 2007). The sample observed consists of persons in management positions in the private sector working full-time. Full-time work is defined as 35 or more contractually agreed weekly working hours, or 35 or more actual weekly working hours if not contractually agreed.

Persons in management positions are defined as being at least 18 years old and having described themselves as white-collar full-time employees in the private sector with

(1) extensive managerial duties (e.g., managing director, manager, head of a large firm or concern) or with

(2) managerial function or highly qualified duties (e.g., scientist, attorney, head of department).

The information on whether the person performs extensive managerial duties or managerial functions/highly qualified duties is controlled for in the models. To compare our results concerning the effects of segregation on wages between managers and non-managers, we also use a sample consisting of white-collar full-time employees who are not in a management position in the private sector.

Our dependent variable is the (logarithmic) gross monthly wages of women and men. Gross monthly wages were used instead of the gross hourly wages because overtime in managerial positions is generally not paid extra. Long working hours are common in management and therefore covered by the monthly income. Hourly earnings would not take this into consideration. Nevertheless, we control for the actual weekly working hours in our models and restrict our sample further to people employed full-time.

The following independent variables are used for the wage estimations: 
Segregation: To measure occupational sex segregation, we take the percentage of women in the current occupation. The variable is not directly available in the SOEP and has been computed by taking the year-specific gender composition in each occupation of the job classification of the German Federal Office of Statistics (3-digit), version 1992 (Federal Office of Statistics, 1992). ${ }^{3}$ Since this variable is not included in the SOEP, these yearspecific values for each year of the observation period have been taken from a special evaluation of the German Microcensus (Federal Office of Statistics, 2008) for the years 20002009 conducted by the German Federal Office of Statistics, and merged via the job classification to the SOEP. For descriptive overviews, the continuous variable has been categorized as men's occupations (percentage of women 0-30 percent), women's occupations (percentage of women 70-100 percent) and integrated occupations (all remaining occupations).

Organization/firm: To show to what extent firm size can explain the gender wage gap and moderate the dependency between working in a segregated occupation and wages, firm size as well as the interaction terms between firm size and the percentage of women within an occupation is included. At this point, it is important to distinguish between firms and subunits of firms: firm refers to the entire company as a legal entity, and sub-units refer to the various plants or branches of the firm in which workers are employed." With regard to wages, the firm can be seen as primary: Firms are the entities with internal labor markets that are able to stratify the promotion opportunities and wages of employees within their various branches or units (Evans \& Leighton, 1988). We also control for the firm's economic sector. The assumption is that wages are higher in manufacturing than in parts of the service sector. Since women less often hold management positions in manufacturing than in the service sector (Holst \& Busch, 2010), this may also exacerbate the gender wage gap in managerial positions and must therefore be controlled for in the models. 
Individual human capital: As important human capital resources for income, we take into account the duration of education (in years), the actual work experience (full-time plus parttime, in years provided as a generated variable by the SOEP), as well as the work experience squared as an indicator of the diminishing marginal utility of the work experience (Mincer, 1974). This variable also indirectly corresponds with age, which we had to drop from our model due to multicollinearity reasons. Furthermore, beside these general human capital endowments, we include the length of employment with current employer (in years) in our model as an indicator for specific human capital accumulation.

Occupational human capital requirements: Human capital is not only controlled for as an individual characteristic but also on the occupational level in the form of qualification requirements for the current job. Including both should more fully capture the gendered occupational sorting mechanisms. To reflect general qualification requirements, we include whether an academic degree is required for the job. To reflect specific human capital requirements, we include whether participation in special training or courses is needed.

Finally, we include further control dimensions in the multivariate analysis:

- To control for the different limitations women and men face due to family responsibilities, we include family status and the number of children aged 16 and below in the household as predictors for earnings (see for the "family gap" in pay e.g. Waldfogel, 1998). In addition, we include information on whether the person lives in East Germany ("new" federal states) or West Germany ("old" federal states): On the one hand, in East Germany, the wages are more compressed than in West Germany. On the other hand, it may be expected that the gender-specific pay differential is lower in the East than in the West due to more egalitarian structures in the "new” federal states (Trappe \& Rosenfeld, 
2004). This may also be reflected in a higher percentage of women in managerial positions in East Germany (Brader \& Lewerenz, 2006; Holst \& Busch, 2010). On the other hand, earning opportunities are worse in East Germany_again one important explanation for the gender wage gap in management positions.

- Technical control: imputation of gross monthly earnings. Non-response to income questions is normally higher than for other questions. This can lead to biases in the results because "item non-response” is generally not distributed proportionally across different groups of the population. Consequently, in our analysis, we use the imputed gross monthly earnings provided in the SOEP (Grabka \& Frick, 2003). We also include a dummy variable that shows whether the income was imputed or not (results not shown in tables.. The technical controls are not reported in the tables.

Selection variables: To estimate the selection into managerial positions (Heckman's correction, see above), for white-collar employees working full-time in the private sector, we predict the probability of being a manager versus NOT being a manager. We include the same independent variables in the selection equation as in the wage equation if they are observable for non-managers as well. Furthermore, we include additional variables: current health (varying from 1 "very good" to 5 "bad”) and information on whether there are children 6 years or younger in the household. In addition, we control for high-income subsample G (results not shown in tables). The SOEP was enlarged in 2002 to include the high-income subsample G (households with a monthly net income of over 3,835 euros) with the objective of providing a more extensive database for the analysis of life circumstances, income, and asset accumulation of households in the upper-income range (Schupp et al., 2003). For our comparison sample in the later models-white-collar employees without managerial duties working full-time in the private sector-we calculate the selection probability of being 
employed (versus not being employed), taking the same selection variables and independent variables that are observable for non-employed persons.

\section{Results}

\section{Descriptives}

The following table gives an overview of the variables for persons in managerial positions employed full-time in the private sector, pooled for the years 2000-2009.

Table 1: Women and men in full-time management positions in the private sector: Overview of predictors 2000-2009

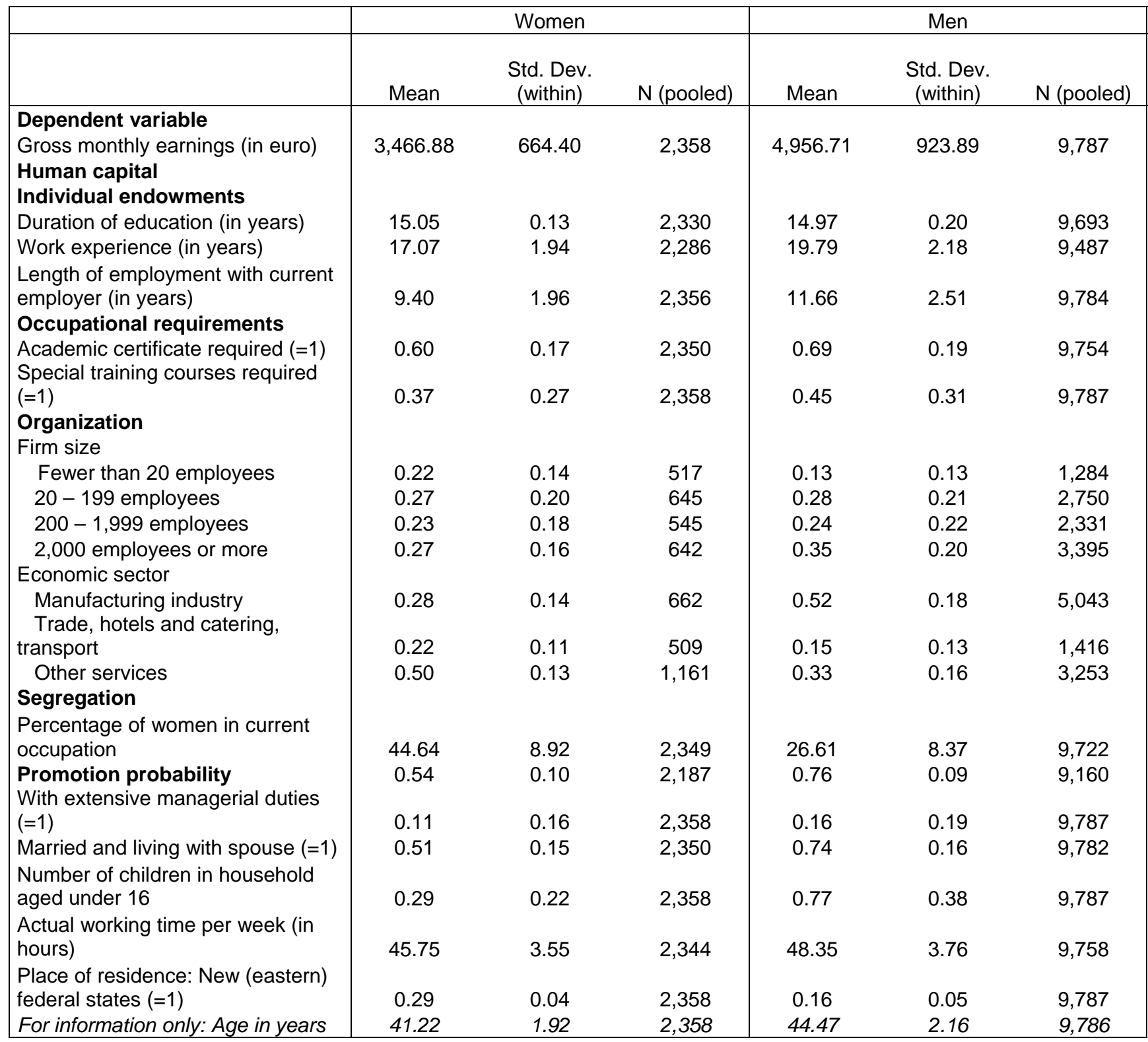

Source: SOEP v26, own calculations. 
With a mean gross monthly income of 3,467 euros in our pooled sample, women earn 70 percent of the male mean income in management positions. Hence, the gender pay gap is 30 percent. As far as education is concerned, the human capital accumulation is balanced: both women and men have on average almost 15 years of education. However, women have 17 years of work experience compared to nearly 20 years for men. This difference is essentially age-related, since women employed in full-time managerial positions in our sample are on average around three years younger than their male counterparts. Furthermore, men work longer on average for the same employer (12 years versus 9 years for women). Differences can also be observed in the human capital requirements of the job: 69 percent of men work in a job requiring an academic degree compared to 60 percent of women. Further, men are more likely than women to hold jobs requiring further training and therefore to possess more specific human capital accumulations. This suggests a selection of women into occupations with lower human capital requirements despite having human capital accumulations comparable to those of men.

Marked differences can also be seen in the variables concerning social structure and family circumstances: compared to men, fewer women in managerial positions are married and they have a lower mean number of children aged 16 and younger in the household. Women's lower chances of promotion can be seen in the mean value of the instrumental variable that is included later in the models to control for selection bias: Women working full-time in the private sector have, on average, a net promotion probability (calculated in the selection equation) of 54 percent. This means that women employed full-time in the private sector have a 54 percent probability of being in a managerial position. Men's promotion probability is much higher at 76 percent.

Strong gender-specific differences can be observed in segregation: The "average male manager” works in an occupation with only 27 percent women and very often in typically 
“male” occupations. In contrast, women in management do not work in very gender-typical "female" jobs; the "average female manager" works in an occupation with 45 percent women, which is nearly gender balanced. This might be due to the assumption that women's occupations provide limited chances of promotion. This is consistent with other results in the research showing that women in management positions are less segregated than other women on the labor market, whereas men in management are more segregated than other men (Holst \& Busch, 2010). Furthermore, it is evident that women more often head small firms, whereas men more often head large firms: Only 13 percent of men but 22 percent of women in our pooled sample have a managerial position in firms with fewer than 20 employees. But 35 percent of men and only 27 percent of women head large firms with 2000 or more employees. For better illustration, Figure 1 again shows the degree of segregation in managerial positions compared to non-managerial positions, taking the categorized segregation variable. Male managers are heavily segregated; 65 percent work in men's occupations, and only a small minority work in women's occupations (5 percent). Female managers are less segregated: The majority (46 percent) works in integrated occupations, and they work more often in men's than in women's occupations. But still, more female managers than male managers work in women's occupations. Therefore, segregation also exists in managerial positions, but on a lower level. The comparison with non-managers shows that women are much more segregated and men less segregated. Therefore, for men, segregation is stronger among managers; for women, segregation is weaker among managers. This indicates a vertical element of segregation; insofar that women's occupations rarely provide managerial jobs, whereas men’s occupations are often those with strong promotion opportunities. 


\section{Figure 1: White-collar employees working full-time in the private sector in}

women's, integrated and men's occupations 2000-2009 (in percent)

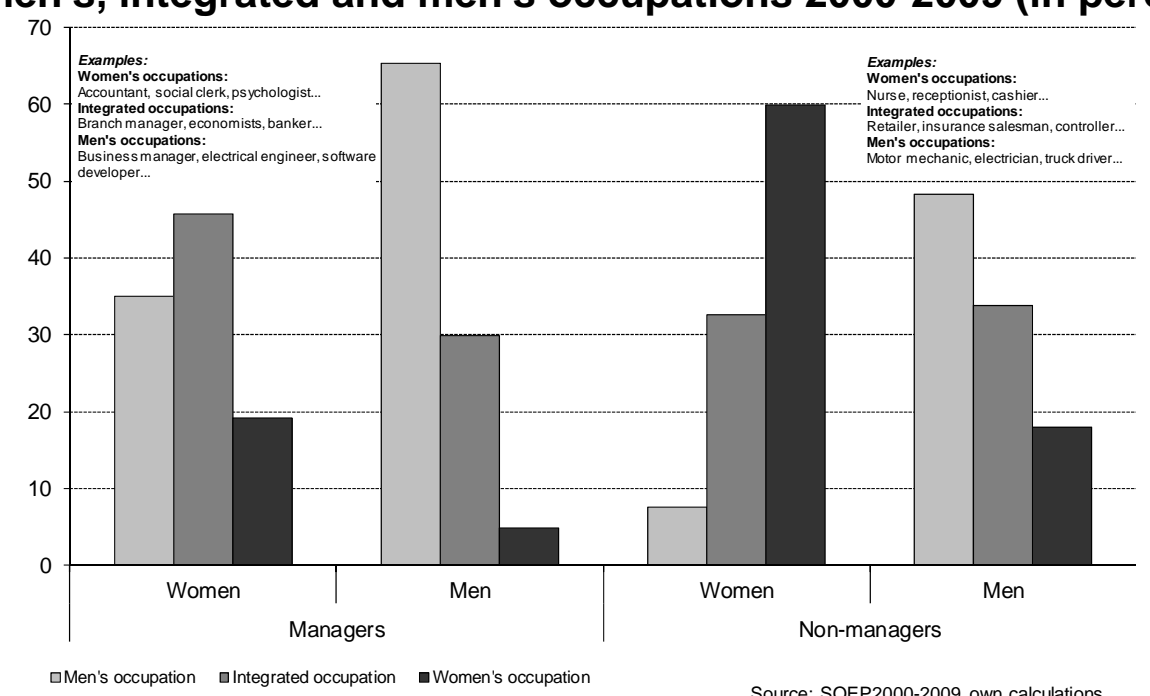

Source: SOEP v26, own calculations.

Figure 2 shows the mean monthly wages for managers working in male occupations and in female/integrated occupations and compares these to figures for non-managers. For men, only marginal differences in wages are observable for managers as well as for non-managers. For female managers there are wage advantages observable when they work in men's occupations. However, the wage advantages are stronger for women who are not managers: Female managers who work in men's occupations earn about 10 percent more than female managers not working in those occupations, whereas female non-managers working in male occupations earn about 20 percent more than those working in other occupations (numbers not shown). Therefore, differences between segregated occupations appear to play a role for women not working in managerial positions. The question is whether the wage penalty in more female occupations for managers are moderated by the size of the firm they work in. 


\section{Figure 2: White-collar employees working full-time in the private sector: Gross monthly wages in segregated occupations 2000-2009 (mean, in Euro)}

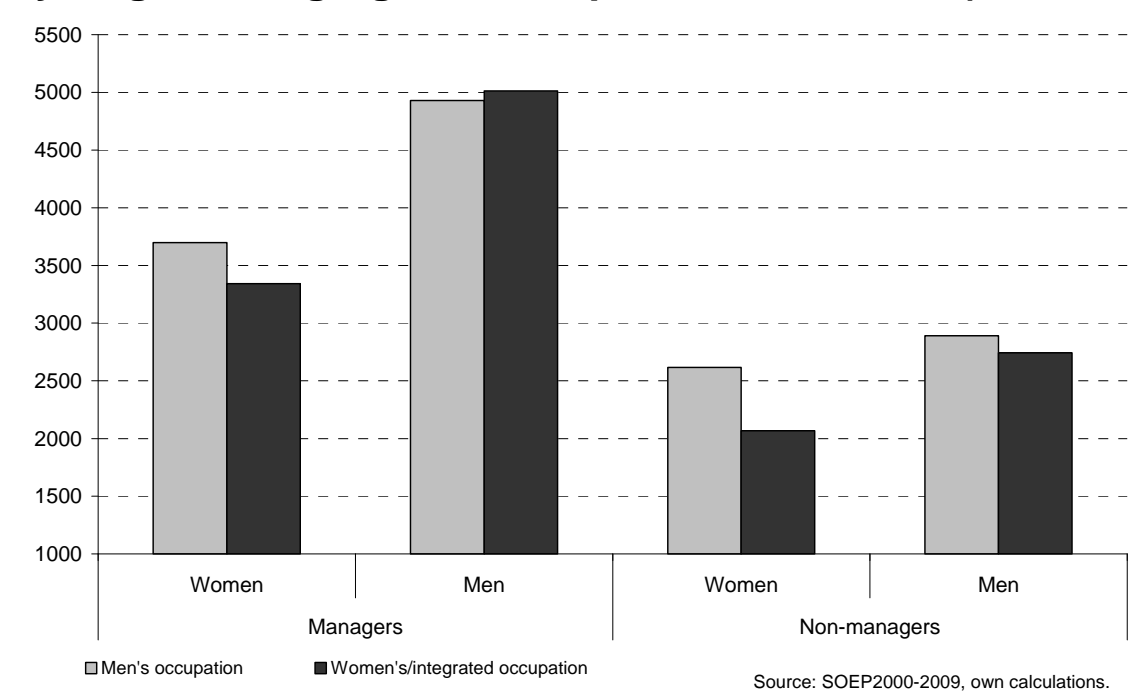

Source: SOEP v26, own calculations.

\section{Multivariate analysis}

Table 2 shows the results of the fixed effects regression for men and women, separated for non-managers and for managers, and states whether the differences in the coefficients between women and men are significant. All models are computed controlling for selection into the sample for managers including the promotion probability and for non-managers the employment probability as instrumental variables.

For non-managers, a significant effect of segregation on wages can be observed: The more "female" the current occupation is, the lower the wages-for women, but not for men. The difference between the coefficients of women and men is significant. Controlling for individual human capital endowments and occupational human capital requirements, this wage penalty for female occupations points to an evaluative devaluation process; the general societal devaluation of work done primarily by women. Since these processes affect women more than men, it can be assumed that aside from this evaluative discrimination, women and men working in the same (male or female) occupation hold different positions with different pay levels, a process known as allocative discrimination (Peterson \& Saporta, 2004). 
Table 2: White-collar employees working full-time in the private sector: Determinants of logarithmic gross monthly wages 2000-2009 (fixed effects model)

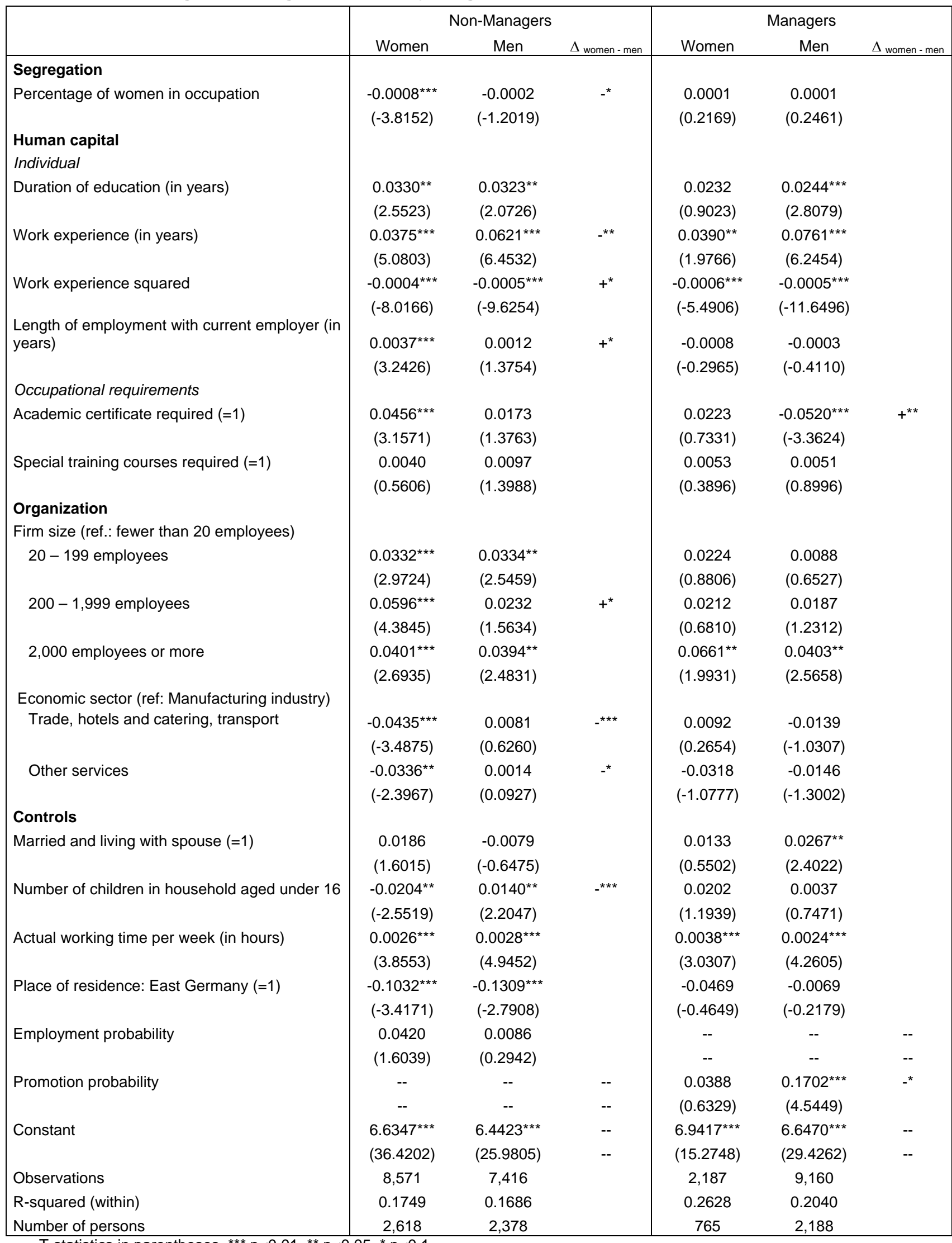

T-statistics in parentheses. ${ }^{* \star} p<0.01,{ }^{* \star} p<0.05,{ }^{*} p<0.1$.

Dependent variable: Logarithm of gross monthly wages.

Controlled for imputed wages, with extensive managerial duties (only for managers), year-dummies.

Source: SOEP v26, own calculations. 
However, the segregation effect diminishes when looking at persons in managerial positions, no matter whether human capital is controlled for or not. ${ }^{4}$ Therefore, in managerial positions, there seems to be no general devaluation of women's occupations observable, confirming hypothesis 1 . In those positions, there are only few occupations left with a high percentage of women and thus high devaluation. Furthermore, typically feminine work content which exacerbates devaluation, is probably seldom part of the everyday responsibilities of those holding such managerial positions. Therefore, both of the aspects (quantitative and qualitative) that promote devaluation are not relevant to a large extent in these positions. This might explain why there is no negative segregation effect observable here.

Individual investments in general human capital accumulation increase wages: The more people invest in education, the higher the wages. Work experience increases wages for both men and women. With growing work experience this effect weakens, which becomes apparent with the negative sign of squared work experience. Only for non-managers do we observe significant differences in the coefficients of the individual human capital effects between women and men: The effect of work experience on wages is somewhat stronger for men than for women, indicating that the accumulated work experience of women has a lower value on the labor market, since for women, work experience is gained to a larger extent through part-time work and women have more breaks in employment. Interestingly, again for non-managers, job tenure affects wages more for women than for men. For men, there is no significant effect observable. This may be due to the assumption that for men, job tenure is highly correlated with work experience, but not as much for women. Men’s career paths are more continuous and often in the same firm; therefore the degree of work experience and the degree of job tenure are more equal for men than for women. ${ }^{5}$

Interestingly, not all of the occupational qualification requirements have effects on wages; one of the effects is even counterintuitive: for male managers, if an academic (e.g., university) degree is required for a job, this lowers male managers' wages. Here it should be taken into 
account that fixed effects models include only "movers" on the labor market, meaning persons who show changes in the variables. Therefore, it may be that individuals who changed jobs from one with lower to one with higher requirements may have special reasons for having done so - for example, trading off initially lower wages in order to attain higher possibilities of promotion in the future-in line with assumptions from human capital theory that wages in highly specialized jobs are low at the beginning but increase strongly in the future.

Interestingly, for non-managers, there is a wage penalty due to the family responsibilities observable for women, whereas having children increases income for men. This is in line with arguments of a "family gap" for women, suggesting that family responsibilities hinder women in their careers and that employed mothers often have the role of secondary earners in the family, whereas men with family responsibilities are often the main breadwinners. For managers, this effect is not observable, indicating that those people have already overcome the labor market barriers to family formation.

Firm size in general has strong effects on wages: in large firms, wages are significantly higher than in smaller firms. The result reflects the assumption that large firms in general have more resources to pay higher wages and offer internal labor markets with possibilities for raises. This effect of firm size on wages is true for men as well as for women but more evident for non-managers than for managers. The question that is not answered yet is to what extent firm size moderates wage penalties in predominantly female occupations.

To find out to what extent firm size moderates the dependency between working in a segregated occupation and wages, interaction variables between firm size and the percentage of women in the current occupation are included (table 3). For non-managers, there is no observable significant moderating effect of firm size on the relationship between working in a female occupation and wages. This indicates that devaluation of female occupations takes place everywhere, no matter if people work in large or small firms. However, the picture 
changes when it comes to managers: Here, the interaction terms indeed reveal wage penalties in women's occupations when differentiating between firm sizes. First of all, the coefficient for the percentage of women in the occupation shows the segregation effect in small firms with fewer than 20 employees (since this category is the reference category of variable "firm size”). Surprisingly, the segregation effect in small firms is slightly positive for women: The more "female" the current occupation is, the higher the wages. Obviously, in small firms, women in management have a wage advantage when working in female-dominated occupations. It is not clear what explains this effect, and more research is needed. One argument might be that in small firms, where relatively more women are managers than in larger firms and therefore "old-boy networks" seem to be less common, female managers have more power to overcome traditional structures of inequitable pay for women's and men's occupations and give women's occupations a slight advantage over men's occupations. 
Table 3: White-collar employees working full-time in the private sector: Determinants of logarithmic gross monthly wages 2000-2009 - interactions between segregation and firm size (fixed effects model)

\begin{tabular}{|c|c|c|c|c|}
\hline & \multicolumn{2}{|c|}{ Non-managers } & \multicolumn{2}{|c|}{ Managers } \\
\hline & Women & Men & Women & Men \\
\hline \multicolumn{5}{|l|}{ Segregation } \\
\hline \multirow[t]{2}{*}{ Percentage women in occupation } & $-0.0008^{* *}$ & -0.0001 & $0.0014^{*}$ & 0.0008 \\
\hline & $(-2.2875)$ & $(-0.3214)$ & $(1.8581)$ & $(1.5122)$ \\
\hline \multicolumn{5}{|l|}{ Organization } \\
\hline \multicolumn{5}{|l|}{ Firm size (ref.: fewer than 20 employees) } \\
\hline \multirow[t]{2}{*}{20 - 199 employees } & $0.0645^{\star \star}$ & 0.0318 & 0.0415 & 0.0191 \\
\hline & $(2.1460)$ & $(1.5841)$ & $(0.9092)$ & $(0.9467)$ \\
\hline \multirow[t]{2}{*}{200 - 1,999 employees } & 0.0333 & $0.0402^{\star}$ & $0.1188^{\star \star}$ & $0.0473^{* *}$ \\
\hline & $(0.9933)$ & $(1.7761)$ & $(2.2321)$ & $(2.1576)$ \\
\hline \multirow[t]{2}{*}{2,000 employees or more } & 0.0201 & $0.0450^{\star}$ & $0.1683^{\star * \star}$ & $0.0687^{\star \star \star}$ \\
\hline & $(0.5927)$ & $(1.9268)$ & $(3.3166)$ & $(3.0808)$ \\
\hline \multicolumn{5}{|l|}{ Interaction terms $^{1}$} \\
\hline \multirow{3}{*}{$\begin{array}{l}\text { Firm size } 20-199 \text { employees } X \text { percentage women in } \\
\text { occupation }\end{array}$} & & & & \\
\hline & -0.0005 & 0.0000 & -0.0004 & -0.0003 \\
\hline & $(-1.1324)$ & $(0.1064)$ & $(-0.5059)$ & $(-0.5911)$ \\
\hline \multirow[t]{2}{*}{$\begin{array}{l}\text { Firm size } 200-1,999 \text { employees } X \text { percentage women in } \\
\text { occupation }\end{array}$} & 0.0004 & -0.0004 & $-0.0021 * *$ & $-0.0010^{*}$ \\
\hline & $(0.9235)$ & $(-1.0015)$ & $(-2.2507)$ & $(-1.7640)$ \\
\hline \multirow{2}{*}{$\begin{array}{l}\text { Firm size } 2,000 \text { and more employees } X \text { percentage } \\
\text { women in occupation }\end{array}$} & 0.0003 & -0.0001 & $-0.0025^{\star * *}$ & $-0.0010^{*}$ \\
\hline & (0.7097) & $(-0.2806)$ & $(-2.6257)$ & $(-1.7391)$ \\
\hline \multirow[t]{2}{*}{ Constant } & $6.6326^{\star \star \star}$ & $6.4347^{\star \star \star}$ & $6.8139^{* * *}$ & $6.6319^{\star * *}$ \\
\hline & $(36.0715)$ & $(25.9019)$ & $(14.9076)$ & $(29.3128)$ \\
\hline Observations & 8,571 & 7,416 & 2,187 & 9,160 \\
\hline R-squared (within) & 0.1757 & 0.1689 & 0.2676 & 0.2046 \\
\hline Number of persons & 2,618 & 2,378 & 765 & 2,188 \\
\hline
\end{tabular}

T-statistics in parentheses. ${ }^{* *} p<0.01,{ }^{* *} p<0.05,{ }^{*} p<0.1$.

Dependent variable: Logarithm of gross monthly wages.

${ }^{1}$ Ref.: Firm size fewer than 20 employees $X$ percentage women in occupation

Controlled for all variables in the models listed in table 2.

Source: SOEP v26, own calculations

However, this slight wage advantage of predominantly female occupations diminishes and turns negative in larger firms, as observable in the interaction terms. This is especially true for women, indicating a devaluation of female occupations in large firms, since we control for human capital. The observation may reflect certain processes of gender-specific discrimination that are more prevalent in large firms, despite the research finding that segregation itself is less prevalent in such firms and that wages in general are higher. Organizational structures may be more "gendered" than in small firms when it comes to devaluation. This may be due to the fact that large firms are older, more formalized, and have more entrenched "old-boy networks," and therefore more sluggish in reacting to societal 
changes toward gender egalitarianism. Processes devaluing women's occupations and attributing higher values to men's occupations may therefore be more evident in these firms. Furthermore, in large firms, wages can be assumed to vary more widely between predominantly male and predominantly female occupations, because men's occupations tend to have more very highly paid top positions, whereas predominantly female occupations do not show significant variation in wages between small and large firms. Therefore, the wage dispersion between male and female occupations is less pronounced in smaller firms.

To show the net dependency between the percentage of women in the current occupation on wages, moderated by the firm size, as shown in Table 3, conditional effect plots have been applied (Kohler \& Kreuter, 2008). All continuous independent variables, except the percentage of women in the current occupation, have been centered by subtracting the sample mean women and men, respectively.

Controlling for all other variables, and taking unobserved time constant heterogeneity and selection into management into account, we observe increasing wages with the increasing rate of women in the occupation in small firms with fewer than 20 employees (Figure 3). This positive relationship decreases but remains positive for persons working in firms with 20-199 employees. In larger firms with 200-1,999 employees, the situation changes completely; here, a wage penalty for individuals working in women's occupations compared to those working in more male occupations can be observed. In the largest firms with 2,000 employees and more, this wage penalty in female occupations is largest. For male managers, similar effects can be observed, but on a lower level.

From this it follows that working in large firms generally tends to have wage advantages since wages are higher for both men and women (for managers and also for non-managers). But this is true only for those working in men's occupations. For those working in women's occupations, there are no wage advantages observable in large firms, and this is especially 
true for women. Mechanisms of devaluation of women's work diminish positive wage effects for those occupations in large firms.

Figure 3: Women and men in full-time management positions in the private sector: Gross monthly earnings in segregated occupations and in companies with different firm size 2000-2009 (conditional effects plot)

Women

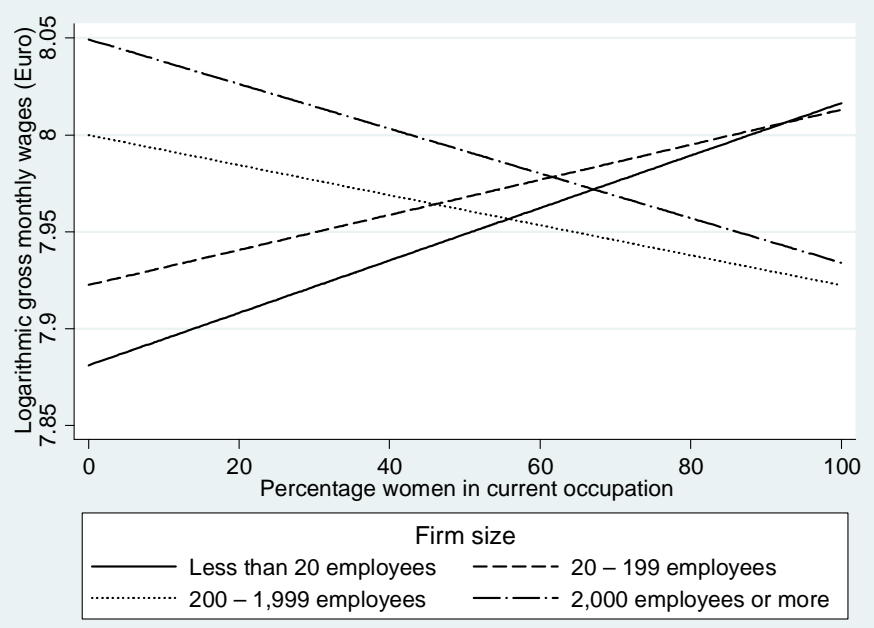

Men

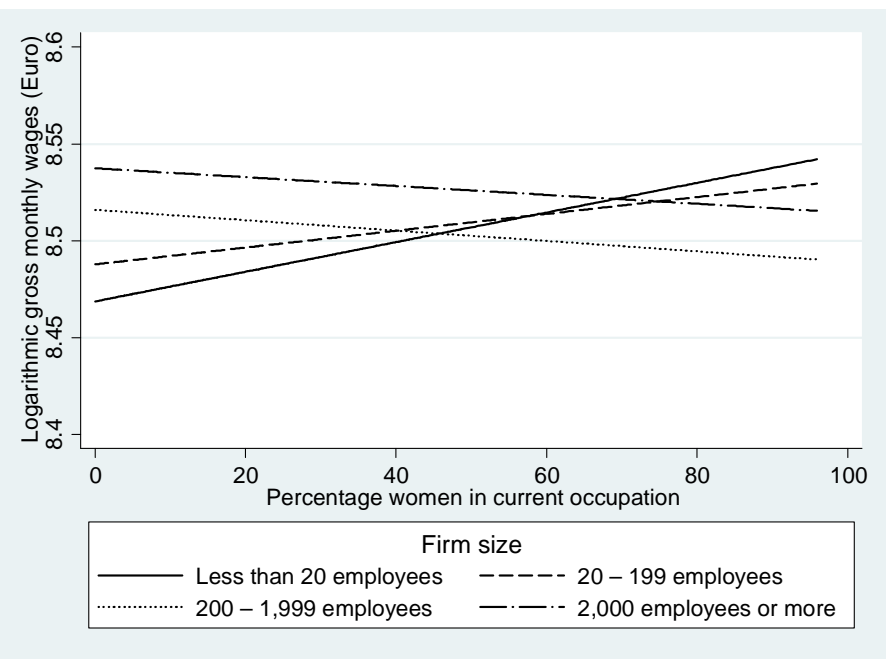

Source: SOEP 2000-2009, own calculations.

\section{Conclusions}

The objective of this paper was to explain the effect of occupational sex segregation on wages for managerial positions in Germany, and to determine the extent to which this effect is moderated by firm size, using data from the German Socio-Economic Panel Study (SOEP). We applied a fixed effects model approach to control for stable unobserved heterogeneity, and we also controlled for selection into the sample using Heckman's correction to obtain unbiased estimators.

The results of our models clearly confirm our working hypotheses: occupational sex segregation in general does not have significant effects on wages in management positions. The results were different for non-managers, where we found significant wage penalties of female occupations for women that might be due to devaluation (since we controlled for 
human capital characteristics). We explain this difference in the segregation effect between managers and non-managers by the vertical dimension of segregation: Women's occupations are often located at low hierarchical levels and less often in management. Management positions are uncommon in female occupations, which are particularly devalued on the labor market. The remaining female occupations in management are more similar to men's jobs in their human capital requirements. Furthermore, it can be assumed that typical feminine tasks that are valued lower on the labor market and that could lead to additional devaluation are less often part of the typical work content of management positions. Therefore, neither the quantitative and qualitative conditions for devaluation are given, resulting in a non-significant segregation effect for managers.

Furthermore we showed that wage penalties of women's occupations exist for managers as well, but only in large firms. This suggests a devaluation of women's occupations in large firms, despite the finding in the literature that segregation itself is less prevalent and wages in general are higher there. This stronger devaluation may be due to large firms being older, more formalized, with more entrenched "old-boy networks," and therefore more sluggish in reacting to societal changes toward increased gender egalitarianism. It may also be due to an increased value assigned to the very highly paid top positions in large firms, which are at the same time men's occupations, whereas women's occupations do not vary as widely in wages between small and large firms.

Interestingly we found a positive effect in small firms for women, showing higher wages for those who work in women's occupations. It is not clear what underlies this effect, and more research is needed to explain this. One argument may be that in small firms-where larger proportions of women are managers and "old-boy networks" may therefore be less common-female managers have more power to overcome traditional structures of inequitable pay for women's and men's occupations and to give predominantly female occupations a slight advantage over men's occupations. 
How can devaluation of women's occupations be reduced in large firms? One possibility is to "simply" increase the percentage of female managers in these firms. This may help to decrease gendered structures and the devaluation of women's occupations. Here, small firms might serve as an example of “best practices,” because here, a larger percentage of women are managers and the devaluation of predominantly female occupations is much lower. More transparency in companies concerning wages, recruitment and promotion is needed to support this.

\section{References}

Achatz, J. (2008). Die Integration von Frauen in Arbeitsmärkten und Organisationen. In S. M. Wilz (Ed.), Geschlechterdifferenzen - Geschlechterdifferenzierungen. Ein Überblick über gesellschaftliche Entwicklungen und theoretische Positionen. 1. Auflage (pp. 105-138). Wiesbaden: VS Verlag.

Achatz, J., Beblo, M., \& Wolf, E. (2010). Berufliche Segregation. In Projektgruppe GiB (Ed.), Geschlechterungleichheiten im Betrieb. Arbeit, Entlohnung und Gleichstellung in der Privatwirtschaft (pp. 89-139). Berlin: Edition Sigma.

Achatz, J., Fuchs, S., von Stebut, J., \& Wimbauer, C. (2002). Geschlechterungleichheit in Organisationen. Zur Beschäftigungslage hochqualifizierter Frauen. In J. Allmendinger \& T. Hinz (Eds.), Organisationssoziologie. Sonderheft Nr. 42/2002 der Kölner Zeitschrift für Soziologie und Sozialpsychologie (pp. 284-318). Wiesbaden: Westdeutscher Verlag.

Achatz, J., Gartner, H., \& Glück, T. (2005). Bonus oder Bias? Mechanismen geschlechtsspezifischer Entlohnung. Kölner Zeitschrift für Soziologie und Sozialpsychologie, 57(3), 466-493. 
Acker, J. (1990). Hierarchies, Jobs, Bodies: A Theory of Gendered Organizations. Gender and Society, 4(2), 139-158.

Allison, P. D. (2009). Fixed Effects Regression Models. London/Thousand Oaks/New Delhi: Sage.

Allmendinger, J., \& Hinz, T. (2007). Geschlechtersegregation in Organisationen und die Lohndifferenz zwischen Männern und Frauen. In R. Gildemeister \& A. Wetterer (Eds.), Erosion oder Reproduktion geschlechtlicher Differenzierungen?: Widersprüchliche Entwicklungen in professionalisierten Berufsfeldern und Organisationen (pp. 172-188). Münster: Westfälisches Dampfboot.

Allmendinger, J., \& Podsiadlowski, A. (2001). Segregation in Organisationen und Arbeitsgruppen. In B. Heintz (Ed.), Geschlechtersoziologie. Sonderheft Nr. 41/2001 der Kölner Zeitschrift für Soziologie und Sozialpsychologie (pp. 276-307). Opladen: Westdeutscher Verlag.

Baron, J. N., Hannan, M. T., Hsu, G., \& Koçak, Ö. (2007). In the Company of Women. Gender Inequality and the Logic of Bureaucracy in Start-Up Firms. Work and Occupations, 34(1), 35-66.

Beblo, M., Heinze, A., \& Wolf, E. (2008). Entwicklung der beruflichen Segregation von Männern und Frauen zwischen 1996 und 2005 - Eine Bestandsaufnahme auf betrieblicher Ebene. Zeitschrift für ArbeitsmarktForschung (ZAF), 41(2/3), 181-198.

Becker, G. S. (1975). Human Capital. 2nd Edition. New York: Columbia University Press.

Berger, J., Fisek, H., Norman, R. Z., \& Zelditch, M. (1977). Status Characteristics and Social Interaction: An Expectation States Approach. New York: Elsevier.

Berk, R. A. (1983). An Introduction to Sample Selection Bias in Sociological Data. American Sociological Review, 48, 386-398.

Bertrand, M., \& Hallock, K. F. (2001). The Gender Gap in Top Corporate Jobs. Industrial and Labor Relations Review, 55(1), 3-21. 
Bielby, W. T., \& Baron, J. N. (1983). Organizations, technology, and worker attachment to the firm. Research in Social Stratification and Mobility, 2, 77-113.

Blau, F. D., Ferber, M. A., \& Winkler, A. E. (2006). The Economics of Women, Men and Work. New Jersey: Pearson.

Blau, F. D., \& Kahn, L. M. (2000). Gender Differences in Pay. Journal of Economic Perspectives, 14(4), 75-99.

Blau, F. D., \& Kahn, L. M. (2003). Understanding International Differences in the Gender Pay Gap. Journal of Labor Economics, 21(1), 106-144.

Blumer, H. (1969). Symbolic Interactionism: Perspective and Method. Englewood Cliffs, NJ: Prentice-Hall.

Brader, D., \& Lewerenz, J. (2006). An der Spitze ist die Luft dünn, IAB Kurzbericht Nr. 2. Nürnberg: IAB.

Brüderl, J., \& Schüssler, R. (1990). Organizational Mortality. The Liability of Newness and Adolescence. Administrative Science Quarterly, 35, 530-547.

Busch, A., \& Holst, E. (2010). Der Gender Pay Gap in Führungspositionen: Warum die Humankapitaltheorie zu kurz greift. Femina Politica, 19(2), 91-102.

Busch, A., \& Holst, E. (2011). Gender-Specific Occupational Segregation, Glass Ceiling Effects, and Earnings in Managerial Positions: Results of a Fixed Effects Model, DIW Discussion Paper. Berlin: DIW.

Cohen, P. N., \& Huffman, M. L. (2007). Working for the Woman? Female Managers and the Gender Wage Gap. American Sociological Review, 72(5), 681-704.

Cohen, P. N., Huffman, M. L., \& Knauer, S. (2009). Stalled Progress? Gender Segregation and Wage Inequality Among Managers, 1980-2000. Work and Occupations, 36(4), 318-342.

Correll, S. J., \& Ridgeway, C. L. (2006). Expectation States Theory. In J. Delamater (Ed.), Handbook of Social Psychology (pp. 29-51). New York: Springer. 
Doeringer, P. B., \& Piore, M. M. E. (1971). Internal Labor Markets and Manpower Analysis. Lexington, Massachusetts: Heath Lexington Books.

Eagly, A. H., \& Carli, L. L. (2007). Through the Labyrinth: The Truth About How Women Become Leaders. Boston: Harvard Business School Press.

England, P. (1982). The failure of human capital theory to explain occupational sex segregation. The Journal of Human Resources, 17(3), 358 - 370.

England, P. (1989). A Feminist Critique of Rational-Choice Theories: Implications for Sociology. The American Sociologist, 20(1), 14-28.

England, P. (1992). Comparable Worth. Theories and Evidence. New York: Aldine de Gruyter.

England, P., Farkas, G., Kilbourne, B. S., \& Dou, T. (1988). Explaining occupational sex segregation and wages: Findings from a model with fixed effects. American Sociological Review, 53(4), 544 - 558.

England, P., Hermsen, J. M., \& Cotter, D. A. (2000). The Devaluation of Women's Work: A Comment on Tam. American Journal of Sociology, 105(6), 1741-1751.

European Commission. (2006). The Gender Pay Gap - Origins and Policy Responses. A Comparative Review of 30 European Countries. Luxembourg: Office for Official Publications of the European Communities.

European Commission. (2010). Report on Equality between Women and Men 2010. Luxembourg.

European Commission’s Expert Group on Gender and Employment (EGGE). (2009). Gender Segregation in the Labour Market: Root Causes, Implications and Policy Responses in the EU. Luxembourg: Publications Office of the European Union.

European Foundation for the Improvement of Living and Working Conditions. (2007).

Working conditions in the European Union: The gender perspective. Luxembourg: Office for Official Publications of the European Communities. 
Evans, D. S., \& Leighton, L. S. (1988). Why do Smaller Firms Pay Less? The Journal of Human Resources, 24(2), 299-318.

Federal Office of Statistics. (1992). Klassifizierung der Berufe - Systematisches und alphabetisches Verzeichnis der Berufsbenennungen. Ausgabe 1992. Stuttgart: MetzlerPoeschel.

Federal Office of Statistics. (2008). Mikrozensus 2007. Qualitätsbericht. Wiesbaden: Federal Office of Statistics.

Ferber, M. (1987). Women and Work, Paid and Unpaid: A Selected, Annotated Bibliography. New York/London: Garland Publishing, Inc.

Grabka, M. M., \& Frick, J. R. (2003). Imputation of Item-Non-Response on Income Questions in the SOEP 1984-2002.

Greene, W. H. (2003). Econometric Analysis. Englewood Cliffs, New Jersey: Prentice-Hall.

Heckman, J. J. (1979). Sample Selection Bias as a Specification Error. Econometrica, 47(1), 153-161.

Heinze, A., \& Wolf, E. (2010). The intra-firm gender wage gap: A new view on wage differentials based on linked employer-employee data. Journal of Population Economics, 23(3), 851-879.

Hinz, T., \& Gartner, H. (2005). Geschlechtsspezifische Lohnunterschiede in Branchen, Berufen und Betrieben. Zeitschrift für Soziologie, 34(1), 22-39.

Hinz, T., \& Schübel, T. (2001). Geschlechtersegregation in deutschen Betrieben, Mitteilungen aus der Arbeitsmarkt- und Berufsforschung (Vol. 34, pp. 286-301). Nürnberg: IAB.

Holst, E., \& Busch, A. (2010). Führungskräfte-Monitor 2010, Politikberatung kompakt 56/2010. Berlin: DIW.

Holst, E., \& Schimeta, J. (2011). Twenty-nine Women to 906 Men: Continuing Gender Inequality on the Boards of Germany's Top Companies, DIW Weekly Report. Berlin: DIW. 
Hoppenstedt (Ed.). (2010). Frauen in Führungspositionen. Darmstadt: Hoppenstedt.

Hultin, M., \& Szulkin, R. (2003). Mechanisms of Inequality. Unequal Access to

Organizational Power and the Gender Wage Gap. European Sociological Review, 19(2), 143-159.

Keller, E. F. (1985). Reflections in Gender and Science. New Haven and London: Yale University Press.

Kilbourne, B., England , P., Farkas, G., Beron, K., \& Weir, D. (1994). Returns to Skill, Compensating Differentials, and Gender Bias: Effects of Occupational Characteristics on the Wages of White Women and Men. American Journal of Sociology, 100(3), 689-719.

Kirchmeyer, C. (2002). Gender Differences in Managerial Careers: Yesterday, Today, and Tomorrow. Journal of Business Ethics, 37(1), 5-24.

Kohler, U., \& Kreuter, F. (2008). Datenanalyse mit Stata. Allgemeine Konzepte der Datenanalyse und ihre praktische Anwendung. 3. Auflage. München: Oldenbourg. Lausten, M. (2001). Gender Differences in Managerial Compensation - Evidences from Denmark, Working Papers 01-4, University of Aarhus, Aarhus School of Business, Department of Economics.

Lester, R. A. (1967). Pay Differentials by Size of Establishment. Industrial Relations, 7(1), 57-67.

Leuze, K., \& Strauß, S. (2009). Lohnungleichheiten zwischen Akademikerinnen und Akademikern: Der Einfluss von fachlicher Spezialisierung, frauendominierten Fächern und beruflicher Segregation. Zeitschrift für Soziologie, 38(4), 262-281.

Liebeskind, U. (2004). Arbeitsmarktsegregation und Einkommen. Vom Wert "weiblicher" Arbeit. Kölner Zeitschrift für Soziologie und Sozialpsychologie, 56(4), 630 - 652.

Marini, M. M. (1989). Sex Differences in Earnings in the United States. Annual Review of Sociology, 15, 343-380. 
Marini, M. M., \& Brinton, M. C. (1984). Sex Typing in Occupational Socialization. In B. F. Reskin (Ed.), Sex Segregation in the Workplace. Trends, Explanations, Remedies (pp. 192-232). Washington, DC: National Academy Press.

Maume, D. J. J. (1999). Glass Ceilings and Glass Escalators. Occupational Segregation and Race and Sex Differences in Managerial Promotions. Work and Occupations, 26(4), 483-509.

Mincer, J. (1962). On-the-Job-Training: Costs, Returns and some Implications. Journal of Political Economy, 70(5), 50-79.

Mincer, J. (1974). Schooling, Experience and Earnings. New York: Columbia University Press.

Nelson, J. A. (1996). Feminism, objectivity, and economics. London/New York: Routledge.

Okamoto, D., \& England, P. (1999). Is there a Supply-Side to Occupational Sex Segregation? Sociological Perspectives, 42(4), 557-582.

Peterson, T., \& Saporta, I. (2004). The Opportunity Structure for Discrimination. American Journal of Sociology, 109(4), 852-901.

Polachek, S. W. (1981). Occupational Self-Selection: A Human Capital Approach to Sex Differences in Occupational Structure. The Review of Economics and Statistics, 63(1), 60-69.

Reskin, B. F., McBrier, D. B., \& Kmec, J. A. (1999). The Determinants and Consequences of Workplace Sex and Race Composition. Annual Review of Sociology, 25, 335-361.

Ridgeway, C. L. (1997). Interaction and the Conservation of Gender Inequality: Considering Employment. American Sociological Review, 62(2), 218-235.

Ridgeway, C. L. (2001). Social Status and Group Structure. In M. A. Hogg \& S. Tindale (Eds.), Blackwell Handbook of Social Psychology: Group Processes (pp. 352-375). Oxford, UK: Blackwell. 
Schupp, J., Gramlich, T., Isengard, B., Pischner, R., Wagner, G. G., \& Rosenbladt, B. v. (2003). Repräsentative Analyse der Lebenslageneinkommensstarker Haushalte. Fachlicher Endbericht des Forschungsauftrags für das Bundesministerium für Gesundheit und Soziale Sicherung (BMGS).

Smyth, E., \& Steinmetz, S. (2008). Field of Study and Gender Segregation in European Labour Markets. International Journal of Comparative Sociology, 49(4-5), 257-281.

Steinberg, R. J. (1990). Social construction of skill. Gender, power, and comparable worth. Work and occupations, 17(4), 449-482.

Tam, T. (1997). Sex Segregation and Occupational Gender Inequality in the United States: Devaluation or Specialized Training? The American Journal of Sociology, 102(6), 1652-1692.

Tam, T. (2000). Occupational Wage Inequality and Devaluation: A Cautionary Tale of Measurement Error. American Journal of Sociology, 105(6), 1752-1760.

Trappe, H., \& Rosenfeld, R. A. (2004). Occupational Sex Segregation and Family Formation in the Former East and West Germany. Work and Occupations, 31(2), 155-192.

Waldfogel, J. (1998). Understanding the 'Family Gap' in Pay for Women with Children. Journal of Economic Perspectives, 12(1), 137-156.

West, C., \& Zimmerman, D. H. (1987). Doing Gender. Gender and Society, 1(2), 125-151.

Wirth, L. (2001). Breaking through the glass ceiling: Women in management. Genf: International Labour Organization. 


\section{Notes}

${ }^{1}$ Looking at the demand side of the labor market, the recruitment of workers into highly specialized occupations requiring specific human capital accumulation is risky for the employer: The further training of the worker is cost-intensive for the employer and requires a high continuity in working life. To discourage workers from leaving the job after a short time, these occupations reward continuous employment with high wage increases. As a result, both employees and employers have an interest in maintaining the employment contract for a long time period (Blau et al., 2006).

2 Other studies, however, find that a high level of bureaucracy within establishments decreases, not increases, inequality between women and men (Baron, Hannan, Hsu, \& Koçak, 2007).

${ }^{3}$ This classification for Germany is more appropriate than the ISCO88-code (International Standard Classification of Occupations, version 1988) to show the horizontal segregation and related inequalities because it contains many more job categories than the ISCO88.

${ }^{4}$ Running the model without human capital variables provided an insignificant effect of the occupational segregation variable too (results not shown).

${ }^{5}$ Running the model without the work experience and its square shows a significant positive effect of job tenure on wages for non-managerial men as well (results not shown). 